\title{
KARAKTERISTIK DAN CITARASA COKELAT PUTIH DARI LEMAK KAKAO NON DEODORISASI DAN DEODORISASI
}

\author{
Characteristics And Flavor Of White Chocolate \\ From Non Deodorized And Deodorized Cocoa Butter \\ Sitti Ramlah dan Alfrida Lullung S. \\ Balai Besar Industri Hasil Perkebunan \\ JI.Prof.Dr.Abdurahman Basalamah No. 28 Makassar \\ e: st.ramlah.bbihp@gmail.com
}

\begin{abstract}
White chocolate is the only chocolate that uses the main ingredients of cocoa butter. Deodorization of cocoa butter processing is a stage of the oil purification process which aims to eliminate unpleasant odors and flavors. This study aims to determine the characteristics and flavor of white chocolate from non deodorized cocoa butter and deodorized. White chocolate in this study used two types of cocoa butter, namely non deodorized cocoa butter (A1) and deodorized cocoa butter (A2) and made with two levels of quality based on the amount of cocoa butter used, namely $22 \%$ (B1) and $30 \%$ (B2). The results of the study indicate that white chocolate processed from non deodorized cocoa butter had quality characteristics; moisture content $1.46-1.52 \%$, sugar $48.25-55.76 \%$, fat content $31.99-37.79 \%$, FFA $1.53-1.58 \%$, melting point $42-51^{\circ} \mathrm{C}$, whereas white chocolate processed from deodorized cocoa butter has moisture content $1,55-1.62 \%$, sugar $48.84-54.85 \%$, fat $32.61-36.14 \%$, FFA $1.11-1,15 \%$, melting point $40-49$ ${ }^{\circ} \mathrm{C}$. White chocolate from non deodorized cocoa butter and deodorized has a level of acceptability of the "good" flavor category.
\end{abstract}

Keywords : White chocolate, non deodorization, deodorization, characteristics, flavor

Abstrak: Cokelat putih merupakan satu-satunya cokelat yang menggunakan bahan baku utama lemak kakao. Deodorisasi pada pengolahan lemak kakao adalah suatu tahap proses pemurnian minyak yang bertujuan untuk menghilangkan bau dan rasa yang tidak enak. Penelitian ini bertujuan untuk mengetahui karakteristik dan citarasa cokelat putih dari lemak kakao non deodorisasi dan deodorisasi. Cokelat putih pada penelitian ini menggunakan dua jenis lemak kakao yaitu lemak kakao non deodorisasi (A1) dan lemak kakao deodorisasi (A2) dan dibuat dengan dua tingkat kualitas berdasarkan jumlah lemak kakao yang digunakan, yaitu $22 \%$ (B1) dan $30 \%$ (B2). Hasil penelitian menunjukkan bahwa cokelat putih dari lemak kakao non deodorisasi mempunyai karakteristik mutu ; kadar air 1,46-1,52 \%, kadar gula 48,25 - 55,76 \%, kadar lemak 31,99 - 37,79 \%, FFA 1,53-1,58\%, titik leleh $42-51^{\circ} \mathrm{C}$, sedangkan cokelat putih dari lemak kakao deodorisasi mempunyai kadar air 1,55-1,62 \%, kadar gula 48,84-54,85\%, kadar lemak 32,61 - 36,14\%, FFA 1,11-1,15\%, titik leleh $40-49{ }^{\circ} \mathrm{C}$. Cokelat putih dari lemak kakao non deodorisasi dan deodorisasi mempunyai tingkat keberterimaan citarasa kategori "good".

Kata Kunci: Cokelat putih, non deodorisasi, deodorisasi, karakteristik, citarasa.

\section{PENDAHULUAN}

Kakao merupakan salah satu hasil perkebunan yang dapat memberikan kontribusi untuk peningkatan devisa negara dan memiliki nilai ekonomis yang tinggi. Biji kakao dapat diolah menjadi bermacammacam produk. Salah satu produk antara dari biji kakao adalah lemak kakao. Lemak kakao merupakan produk yang dihasilkan dari pengepresan kakao massa (liquor) dengan menggunakan alat press hidrolik (Francis, 1999).
Lemak kakao merupakan bahan pembawa dan pelarut partikel-partikel pada pasta kakao dan gula serta bahan-bahan lain pada pembuatan produk cokelat susu (Francis, 1999). Lemak kakao berfungsi sebagai matriks pendispersi produk akhir seperti kekerasan, kecerahan, kelumeran pada mulut dari partikel padat kakao, gula dan susu. Lemak kakao juga menentukan kualitas dan kecepatan pelepasan citarasa pada penginderaan (Timms, 2003). Lemak kakao mempunyai sifat yang unik karena mempunyai karakteristik leleh yang spesifik. 
Pada suhu ruangan (sekitar $20^{\circ} \mathrm{C}$ ), lemak kakao bersifat padat dan mulai melembut pada suhu sekitar $30^{\circ} \mathrm{C}$. Lemak kakao meleleh seluruhnya pada suhu sedikit di bawah suhu tubuh. Karakteristik titik leleh inilah menyebabkan lemak kakao lebih disukai untuk pembuatan produk cokelat. Komponen utama penyusun lemak kakao adalah trigliserida yang terbentuk oleh variasi senyawa asam lemak stearat, palmitat dan oleat (Francis, 1999). Jumlah dan posisi ketiga asam lemak tersebut dalam trigliserida mempengaruhi karakteristik leleh lemak. Rasio antara asam lemak jenuh dan asam lemak tidak jenuh pada lemak mempengaruhi konsentrasi lemak yang memadat pada setiap tingkatan suhu. Lemak kakao memiliki sifat khas yakni bersifat plastis dan memiliki kandungan lemak padat yang relatif tinggi. Lemak kakao banyak digunakan sebagai bahan baku produk-produk cokelat. Lemak kakao memiliki rasa dan aroma kakao (Wahyudi,2008).

Lemak kakao mengandung asam oleat, palmitat, stearat, dan pada umumnya dalam 1 molekul trigliserida terikat satu molekul asam oleat dan 2 molekul asam lemak tidak jenuh lainnya. Lemak kakao yang digunakan dalam pembuatan permen cokelat, harus memiliki ciri-ciri yakni akan mencair pada suhu $32-35^{\circ} \mathrm{C}$, mempunyai tekstur yang keras dan sedikit rapuh, serta warnanya tidak buram dan tetap cerah jika dicampur dengan bahan lain serta memadat pada suhu kamar (Ketaren, 2008). Menurut Khomsan (2003), asam stearat merupakan asam lemak netral yang tidak akan memicu kolesterol darah, dan asam oleat merupakan asam lemak yang mempunyai efek positif pada kesehatan jantung.

Deodorisasi pada pengolahan lemak kakao adalah suatu tahap proses pemurnian minyak yang bertujuan untuk menghilangkan bau dan rasa yang tidak enak dalam minyak/ lemak. Menurut Ketaren (2008) komponen minyak/lemak yang menyebabkan bau dan rasa yang tidak enak berasal dari flavor yang dihasilkan dari kerusakan minyak/lemak. Flavor alami ini terdiri dari hidrokarbon tidak jenuh, terpen, sterol, dan tokoferol. Flavor yang dihasilkan dari minyak/lemak biasanya merupakan hasil dari kerusakan minyak/ lemak hasil degradasi trigliserida dalam minyak/lemak, dan menghasilkan asam lemak bebas, aldehid, keton, dikarbonil, alkohol, dan sebagainya. Komponenkomponen flavor tersebut bersifat volatil, sehingga dapat dikurangi dengan proses deodorisasi.

Produsen cokelat pada umumnya memproduksi tiga macam produk cokelat jadi, yaitu cokelat pekat (dark chocolate), cokelat susu (milk chocolate), dan cokelat putih (white chocolate). Ketiga macam produk cokelat ini dibedakan berdasarkan komposisinya, yaitu dari kandungan kakao, gula, serta bahan tambahan lain (Brown, 2010). Selain itu, juga terdapat cokelat jenis couverture yang merupakan cokelat premium yang sering digunakan oleh para profesional di industri untuk membuat pastry ataupun untuk membuat kue (Atkinson et al., 2010).

Cokelat putih merupakan diversifikasi produk dari biji kakao dan merupakan komoditas yang ramai diperdagangan hingga saat ini. Cokelat putih biasa digunakan sebagai bahan pembuatan kue atau untuk diolah menjadi hiasan cokelat lainnya. Semakin berkembangnya industri makanan, maka pemanfaatan cokelat putih juga semakin berkembang terutama untuk hiasan kue dan hiasan produk cokelat. Cokelat putih merupakan satu-satunya cokelat yang menggunakan bahan baku utama lemak kakao. Cokelat putih bukan hanya terdiri dari lemak tetapi juga mengandung karbohidrat dan protein, serta mineral-mineral seperti: zat besi, fosfor, kalium, krom, magnesium, mangan dan lain-lain (Star, 2006). Pada pengolahan cokelat putih, selain lemak kakao sebagai bahan baku, juga ditambahkan susu, gula, lesitin dan vanili.

Saat ini, di Sulawesi Selatan sudah berdiri beberapa industri kecil pengolahan cokelat yang memproduksi jenis cokelat susu (milk chocolate) dan cokelat gelap (dark chocolate), sedangkan jenis cokelat putih (white chocolate) belum dikembangkan, padahal produk cokelat putih ini banyak digunakan pada industri makanan atau pada pembuatan kue. 
Ditinjau dari ketersediaan bahan baku, pengolahan cokelat putih mempunyai potensi yang besar untuk dikembangkan di Sulawesi Selatan, mengingat daerah ini adalah penghasil biji kakao yang merupakan bahan baku untuk menghasilkan lemak kakao. Lemak kakao hasil industri kecil di Sulawesi Selatan umumnya tidak melalui proses deodorisasi seperti yang dilakukan pada industri besar pengolahan lemak kakao.

Pada penelitian ini mencoba mengolah cokelat putih dengan menggunakan lemak kakao yang tidak dideodorisasi (non deodorisasi) hasil dari industri kecil dan lemak kakao yang dideodorisasi yang dihasilkan dari industri pengolahan lemak kakao. Penelitian ini bertujuan untuk mengetahui karakteristik dan citarasa cokelat putih dari lemak kakao non deodorisasi dan deodorisasi .

\section{METODOLOGI}

\section{Bahan Dan Alat}

Bahan baku yang digunakan pada penelitian adalah lemak kakao, gula sukrosa, susu bubuk, lesitin cair, dan vanili. Sedangkan peralatan yang digunakan adalah universal conching, alat tempering, alat cetakan, dan alat penolong lainnya.

\section{Metode Penelitian}

Formula pengolahan cokelat putih pada penelitian ini mengacu kepada Becket (2009). Cokelat putih pada penelitian ini menggunakan dua jenis lemak kakao yaitu lemak kakao non deodorisasi (A1) dan lemak kakao deodorisasi (A2) dan dibuat dengan dua tingkat kualitas berdasarkan jumlah lemak kakao yang digunakan, yaitu $22 \%$ dan $30 \%$, dengan perlakuan sebagai berikut :

\section{Perlakuan :}

A : Jenis Lemak Kakao:

A1: Lemak Kakao non deodorisasi

A2: Lemak Kakao deodorisasi

B: Persentase Lemak Kakao yang ditambahkan/digunakan:

B1 : Penambahan Lemak Kakao $22 \%$

B2 : Penambahan Lemak Kakao $30 \%$

Tabel 1. Formula Cokelat Putih Dari Beberapa Perlakuan

\begin{tabular}{ccccc}
\hline \multirow{2}{*}{ KOMPOSISI } & \multicolumn{4}{c}{ PERLAKUAN (\%) } \\
\cline { 2 - 5 } & A1B1 & A1B2 & A2B1 & A2B2 \\
\hline Lemak kakao & 22 & 30 & 22 & 30 \\
\hline Susu & 29.5 & 32,5 & 29.5 & 32,5 \\
\hline Gula & 48 & 37 & 48 & 37 \\
\hline Lesitin & 0.5 & 0,5 & 0.5 & 0,5 \\
\hline Total & 100 & 100 & 100 & 100
\end{tabular}

\section{Prosedur Penelitian}

Diagram proses pembuatan cokelat putih melalui tahap-tahap yang ditampilkan di Gambar 1.

\section{Parameter Uji}

Parameter uji yang digunakan pada penelitian ini adalah: Kadar Air (SNI 012891-1992), Kadar Gula (SNI 01-28921992), Kadar lemak (SNI 3748:2009), Kadar Asam Lemak Bebas/FFA (SNI 3748:2009), Titik Leleh (WRS200), Uji Mikrobiologi/ Angka Lempeng Total (SNI 7934:2014), Uji Organoleptik (skala hedonik), Uji Citarasa (panelis terlatih), Asam Lemak (HPLC), Asam Amino (HPLC).

Pengujian dilakukan pada Lab. BBIHP (Kadar air, kadar lemak, mikrobiologi / Angka Lempeng Total, Uji organoleptik dengan metode skala hedonik, Kadar gula, Uji organoleptik), Lab. Politeknik UNHAS (melting point/titik leleh), Lab. Saraswanti Bogor (Asam Lemak dan Asam Amino), dan Lab. Puslitkoka Jember (uji citarasa). 




Gambar 1. Diagram alir proses pembuatan Cokelat Putih

\section{Analisis Data}

Analisis data dilakukan berdasarkan analisis staistik deskriptif.

\section{HASIL DAN PEMBAHASAN}

\section{Kadar Air}

Hasil analisa kadar air dari beberapa produk cokelat putih yang dihasilkan pada penelitian ini, dapat dilihat pada Gambar 2.

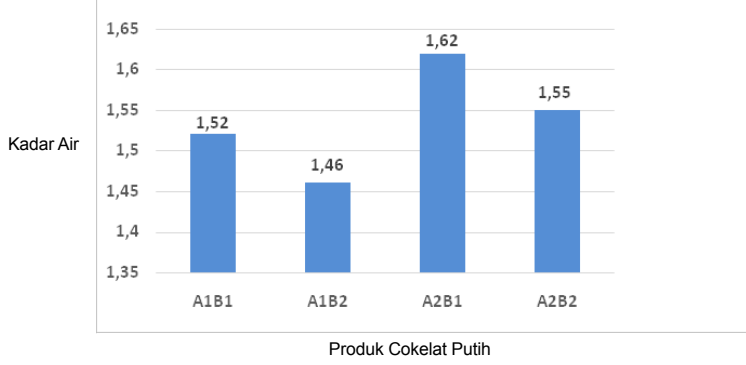

Gambar 2. Histogram kadar air produk cokelat putih berdasarkan perlakuan konsentrasi gula dan jenis lemak kakao

Pada Gambar 2, dapat diilihat bahwa kadar air produk cokelat putih yang dihasilkan berkisar antara 1.46\% - 1,62\%. Cokelat putih dari semua perlakuan yaitu A1B1, A1B2, A2B1 dan A2B2 yang berarti memenuhi syarat mutu SNI 7934 : 2014 ditinjau dari segi parameter kadar air yaitu maksimal 2 $\%$. Pada umumnya kadar air produk yang dihasilkan dari penelitian ini dipengaruhi oleh kandungan air dari bahan baku yang digunakan dan proses pengolahan produk yang digunakan.

\section{Kadar Gula}

Hasil analisa kadar gula yang dilakukan terhadap beberapa produk cokelat putih yang dihasilkan, dapat dilihat pada Gambar 3. Pada Gambar 3, dapat diilihat bahwa kadar gula produk cokelat putih yang dihasilkan dari masing-masing perlakuan adalah 55,76 \% (A1B1), 48,25 (A1B2), 54,85 (A2B1) dan 48,84 $\%$ (A2B2). Tingginya kadar gula pada perlakuan (A1B1 dan A2B1) jika dibandingkan dengan perlakuan (A1B2 dan A2B2), disebabkan karena perbedaan penambahan gula yang diberikan. Penambahan gula pada perlakuan A1B1 dan A2B1 sebanyak $48 \%$, sedangkan perlakuan A1B2 dan A2B2 hanya $37 \%$ (Tabel 1). Peningkatan kadar gula dari jumlah kadar gula yang ditambahkan (48\% pada B1 dan $37 \%$ pada B2) pada masing-masing perlakuan diduga disebabkan selama pengolahan terjadi penurunan kadar air sehingga akan menyebabkan persentase total padatan akan meningkat termasuk kadar gula.

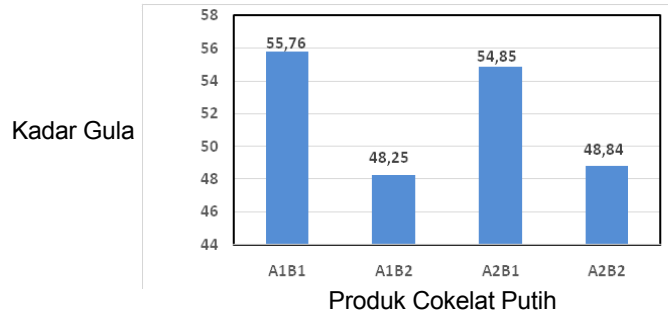

Gambar 3. Histogram kadar gula produk cokelat putih berdasarkan perlakuan konsentrasi gula dan jenis lemak kakao

\section{Kadar Lemak}

Kandungan lemak cokelat putih dipengaruhi oleh formula dan bahan baku yang digunakan. Gambar 4 menunjukkan hasil analisa kadar lemak pada berbagai produk cokelat putih. Pada Gambar 4 dapat diilihat bahwa kadar lemak produk cokelat putih untuk perlakuan A1B1 adalah 31,99\%, A2B1 ( 32,61 \%) , A1B2 (37,79 \%) dan A2B2 $(36,14 \%)$. Terjadinya peningkatan kadar lemak pada A1B2 dan A2B2 disebabkan pada perlakuan ini penggunaan lemak kakao lebih tinggi dibanding pada perlakuan A1B1 dan A2B1. Hasil analisa menunjukkan terjadinya peningkatan kadar lemak dari jumlah lemak kakao yang ditambahkan (22\% 
dan $30 \%$ ) pada masing-masing perlakuan, juga disebabkan penggunaan susu bubuk full cream yang juga mengandung lemak sekitar $11 \%$. Selain itu selama pengolahan terjadi penurunan kadar air sehingga akan menyebabkan persentase komponen penyusun lain dari produk yang tidak larut akan meningkat. Ditinjau dari kandungan lemak, maka cokelat putih yang dihasilkan dari semua perlakuan atau formula memenuhi syarat mutu SNI 7934:2914 yaitu mengandung total lemak $\geq 25 \%$.

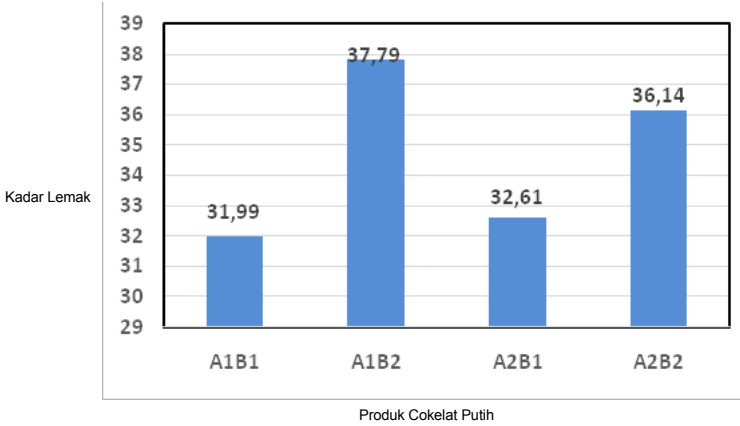

Gambar 4. Histogram kadar lemak produk cokelat putih berdasarkan perlakuan konsentrasi gula dan jenis lemak kakao

\section{Kadar Asam Lemak Bebas (FFA)}

Kadar asam lemak bebas dari beberapa produk cokelat putih pada penelitian ini, disajikan pada Gambar 5. Pada Gambar 5, dapat diilihat bahwa kadar FFA produk cokelat putih yang dihasilkan masingmasing 1,58 \% (A1B1), 1,53 \% (A1B2), 1,15 $\%$ (A2B1) dan 1,11 \% (A2B2). Hasil analisa ini menunjukkan bahwa cokelat putih yang menggunakan lemak kakao deodorisasi A2B1 dan A2B2 memiliki kandungan FFA yang lebih rendah dari cokelat putih yang menggunakan lemak kakao non deodorisasi. Menurut Minifie (1999), proses deodorisasi adalah suatu tahap proses pemurnian minyak yang bertujuan untuk menghilangkan bau dan rasa yang tidak enak dalam minyak/lemak. Selanjutnya Ketaren (2008) mengemukakan bahwa komponen minyak lemak yang menyebabkan bau dan rasa yang tidak enak dalam minyak/lemak berasal dari flavor yang dihasilkan dari kerusakan minyak/lemak. Flavor alami ini terdiri dari hidrokarbon tidak jenuh, terpen, sterol, dan tokoferol. Flavor yang dihasilkan dari minyak lemak biasanya merupakan hasil dari kerusakan minyak lemak yang merupakan hasil degradasi trigliserida dalam minyak/ lemak, yang menghasilkan asam lemak bebas, aldehid, keton, dikarbonil, alkohol, dan sebagainya. Komponen-komponen flavor tersebut bersifat volatil, sehingga dapat dikurangi dengan proses deodorisasi, sehingga parameter keberhasilan deodorisasi adalah penurunan kadar asam lemak bebas dan bilangan peroksida. Proses deodorisasi menyebabkan lemak kakao yang dideodorisasi mempunyai kandungan FFA yang lebih rendah dibanding dengan lemak kakao yg tidak mengalami proses deodorisasi (non deodorisasi), sehingga produk cokelat putih yang dihasilkan mempunyai kandungan FFA yang berbeda pula, namun masih memenuhi syarat mutu SNI 3748 : 2009.

Pada dasarnya tahapan deodorisasi merupakan proses pelepasan steam secara vakum dengan menggunakan suhu tinggi dan bertujuan untuk menghasilkan minyak yang tidak memiliki rasa dan tidak memiliki bau karena teruapkannya asam lemak bebas (FFA) dan komponen volatil berdasarkan perbedaan titik didih setiap komponennya. Menurut Gibon et al., (2007), proses deodorisasi ini melibatkan 3 operasi yang berbeda, yaitu (1) distilasi, yaitu pelepasan komponen volatil (FFA, tokoferol, tokotrienol, dan sterol); (2) deodorisasi, yaitu penghilangan komponen yang berbau, dan (3) pemanasan, yaitu terjadinya perusakan pigmen (karotenoid) karena adanya perlakuan panas tetapi mencegah reaksi isomerisasi dan polimerisasi.

Asam lemak bebas adalah asam lemak yang berada dalam keadaan bebas, tidak terikat sebagai trigliserida.Keberadaan asam lemak bebas (FFA) di dalam lemak kakao harus dihindari karena hal itu merupakan salah satu indikator kerusakan mutu. Kadar asam lemak bebas seharusnya kurang dari 1\%. Sedangkan menurut SNI 3748:2009 maksimum asam lemak bebas $1,75 \%$ pada lemak kakao dan paling baik adalah < 1,3\% (Mulato et al., 2010; Wahyudi et al ., 2015). 
Gambar 5 menunjukkan bahwa kadar FFA lemak putih yang diolah dari lemak kakao non deodorisasi lebih tinggi dibanding cokelat putih yang diolah dari lemak kakao deodorisasi.

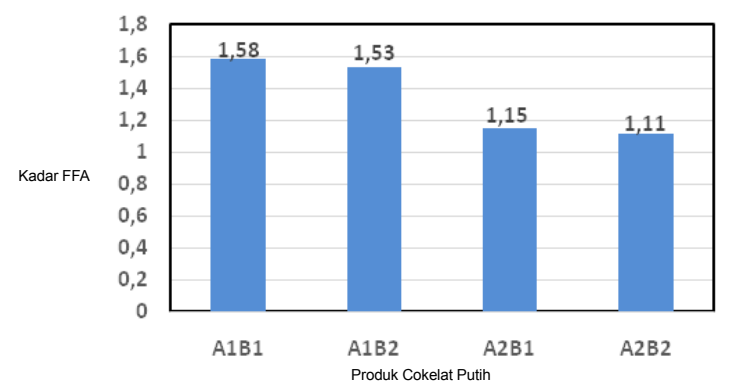

Gambar 5. Histogram kadar lemak produk cokelat putih berdasarkan perlakuan konsentrasi gula dan jenis lemak kakao

\section{Titik Leleh}

Titik leleh adalah temperatur dimana zat padat berubah wujud menjadi zat cair pada tekanan 1 atmosfer. Titik leleh lemak kakao yang baik untuk makanan cokelat mendekati suhu badan manusia dengan tingkat kekerasan minimum pada suhu kamar. Titik leleh lemak merupakan salah satu penentu utama tekstur dan kekerasan cokelat. Cokelat yang baik adalah cokelat yang tidak mencair dalam suhu ruang tetapi meleleh ketika di dalam mulut, sehingga memberikan mood feeling yang lembut. Hasil pengujian terhadap titik leleh dari berbagai cokelat putih yang dihasilkan pada penelitian ini, dapat dilihat pada Gambar 6. Gambar 6 memperlihatkan bahwa titik leleh dipengaruhi oleh penambahan atau jumlah lemak kakao yang digunakan pada pembuatan cokelat putih. Cokelat putih dengan penambahan lemak kakao $30 \%$ yaitu perlakuan A1B2 dan A2B2 mempunyai titik leleh yang lebih rendah dari pada titik leleh cokelat putih A1B1 dan A2B1. Pangerang (2012) mengemukakan bahwa semakin banyak lemak kakao yang ditambahkan, semakin rendah titik leleh dari produk yang dihasilkan. Penambahan lemak kakao dalam jumlah banyak akan menyebabkan cokelat mudah meleleh.

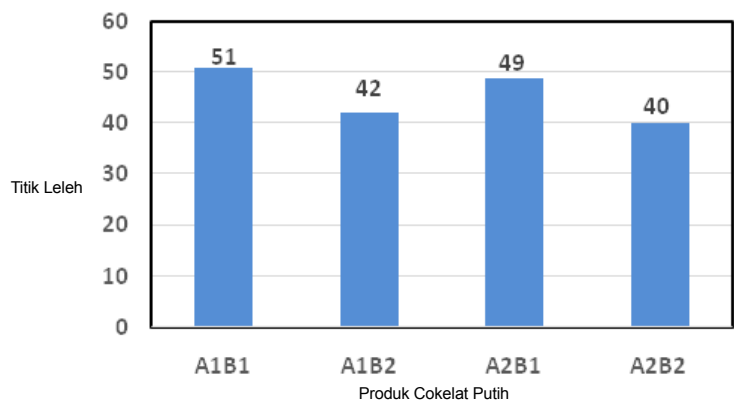

Gambar 6. Histogram kadar lemak produk cokelat putih berdasarkan perlakuan konsentrasi gula dan jenis lemak kakao

Dari Gambar 6 terlihat pula bahwa titik leleh cokelat putih yang dihasilkan dari semua perlakuan lebih tinggi dari titik leleh lemak kakao itu sendiri yang hanya berkisar $31-35^{\circ} \mathrm{C}$. Cokelat putih yang dihasilkan dari perlakuan A1B1 dan A2B1 mempunyai titik leleh yang lebih tinggi dibanding cokelat putih dari perlakuan A1B2 dan A2B2. Hal ini diduga disebabkan oleh kadar gula cokelat putih A1B1 dan A2B1 mempunyai kadar gula yang lebih tinggi dibanding dengan cokelat putih A1B2 dan A2B2. Semakin tinggi jumlah gula pasir yang ditambahkan pada pembuatan cokelat putih maka akan semakin tinggi pula kadar gula cokelat putih yang dihasilkan. Gula pasir dengan rumus molekul $\mathrm{C}_{12} \mathrm{H}_{22} \mathrm{O}_{11}$ diperoleh dari gula tebu yang mengalami proses pemurnian hingga mencapai kadar sukrosa $99,5 \% \mathrm{~b} / \mathrm{b}$, dimana sukrosa memiliki kristal bersifat amorphis, dengan titik leleh $160{ }^{\circ} \mathrm{C}$ pada tekanan 1 atmosfer. Titik leleh sangat dipengaruhi oleh berat molekul zat dan bentuk simetris molekul. Perbedaan titik leleh senyawa-senyawa dipengaruhi oleh beberapa hal, diantaranya perbedaan kuatnya ikatan yang dibentuk antar unsur dalam senyawa tersebut. Semakin kuat ikatan yang dibentuk, semakin besar energi yang diperlukan untuk memutuskannya. Dengan demikian semakin tinggi juga titik leleh unsur tersebut (Anonim, 2014).

\section{Uji Mikrobiologi}

Hasil pengujian mikrobiologi (Angka Lempeng Total) produk cokelat putih dapat dilihat pada Tabel 2. Dari Tabel 2, diketahui bahwa angka lempeng total pada produk 
cokelat putih yang dihasilkan berkisar antara $3.5 \times 10^{1}-1.0 \times 10^{2} \mathrm{koloni} / \mathrm{g}$. Jika ditinjau dari Angka Lempeng Total, maka cokelat putih yang dihasilkan dari semua perlakuan/formula memenuhi syarat mutu SNI 7934:2914 tentang cokelat dan produkproduk cokelat Total maksimal $1 \times 10^{4}$ koloni /g). Pada penelitian ini, higienitas peralatan dan lingkungan sangat diperhatikan untuk menghasilkan produk yang aman untuk dikonsumsi. Selain itu proses pengolahan cokelat putih melalui proses conching dengan menggunakan suhu $70^{\circ} \mathrm{C}$ selama 4 jam dapat menekan perkembangan mikrobiologi. Ramlah dan Yumas (2017) mengemukakan bahwa cemaran mikroba, termasuk angka lempeng total pada suatu produk dipengaruhi oleh beberapa hal, diantaranya adalah bahan baku dan peralatan yang digunakan serta proses pengolahannya.

Tabel 2. Hasil Pengujian Angka Lempeng Total Beberapa Cokelat Putih

\begin{tabular}{cc|}
\hline Cokelat Putih & Hasil (koloni/g) \\
\hline A1B1 & $1.0 \times 10^{2}$ \\
\hline A1B2 & $5.5 \times 10^{1}$ \\
\hline A2B1 & $3.5 \times 10^{1}$ \\
\hline A2B2 & $4.5 \times 10^{1}$ \\
\hline
\end{tabular}

\section{Asam Lemak}

Asam lemak adalah suatu senyawa golongan asam karboksilat yang mempunyai rantai alifatik panjang, baik jenuh maupun tak jenuh. Asam lemak alami mempunyai rantai dengan jumlah atom karbon genap dari 4 hingga 28. Asam lemak merupakan turunan dari trigliserida atau fosfolipid. Asam lemak bebas adalah asam lemak yang tidak terikat pada molekul lain. Asam lemak merupakan sumber bahan bakar makhluk hidup yang sangat penting, karena ketika termetabolisme, asam lemak menghasilkan ATP dengan jumlah yang besar. Beberapa tipe sel dapat menggunakan karbohidrat ataupun asam lemak sebagai bahan bakar.
Tabel 3. Hasil Analisa Asam Lemak Cokelat Putih

\begin{tabular}{lccccc}
\hline Parameter & Unit & A1B1 & A1B2 & A2B1 & A2B2 \\
\hline $\begin{array}{l}\text { Asam } \\
\text { Palmitat }\end{array}$ & $\%$ & 11.17 & 14.47 & 9.94 & 11.56 \\
\hline $\begin{array}{l}\text { Asam } \\
\text { Stearat }\end{array}$ & $\%$ & 13.08 & 13.58 & 11.21 & 12.80 \\
\hline $\begin{array}{l}\text { Asam } \\
\text { Oleat } \\
\text { (W9C) }\end{array}$ & $\%$ & 9.58 & 11.21 & 9.92 & 11.12 \\
\hline $\begin{array}{l}\text { Asam } \\
\text { Linoleat }\end{array}$ & $\%$ & 0,59 & 0.66 & 0.56 & 0.63 \\
\hline
\end{tabular}

Hasil analisa asam lemak dan asam amino pada berbagai cokelat putih, dapat dilihat pada Tabel 3. Hasil penelitian menunjukkan bahwa asam lemak yang dominan pada cokelat putih yang dihasilkan adalah asam palmitat, asam stearat dan asam oleat. Komposisi asam lemak bervariasi, tergantung pada sifat tekstur makanan cokelat dalam proses pembuatannya. Lemak kakao mempunyai sifat khas yaitu bersifat plastis, dan memiliki kandungan lemak padat yang relatif tinggi (Wahyudi, 2008). Kekerasan dari lemak kakao tergantung pada kandungan asam lemak jenuh dan tak jenuh yang terikat pada trigliserida dan pada kandungan asam lemak bebasnya (Guehi et al., 2008). Tabel 3 menunjukkan bahwa produk cokelat putih yang dihasilkan mengandung asam stearat, asam palmitat dan asam oleat yang tinggi. Asam stearat tertinggi diperoleh pada perlakuan A1B2 sebesar 13,58 dan $\%$ asam stearat terendah pada perlakuan A2B1 sebesar 11,21\%. Kandungan asam palmitat tertinggi adalah cokelat putih A1B2 sebesar $14,47 \%$ dan terendah adalah cokelat putih A2B1 sebesar $9,94 \%$. Sedangkan kandungan asam oleat tertinggi adalah cokelat putih A1B2 sebesar $11,21 \%$ dan terendah cokelat putih A1B1 sebesar $9,58 \%$.

Asam stearat, atau asam oktadekanoat, adalah asam lemak jenuh yang mudah diperoleh dari lemak hewani serta minyak masak. Wujudnya padat pada suhu ruang, dengan rumus kimia $\mathrm{CH}_{3}\left(\mathrm{CH}_{2}\right)_{16} \mathrm{COOH}$. Titik lebur asam stearat $69,6{ }^{\circ} \mathrm{C}$ dan titik didihnya $361^{\circ} \mathrm{C}$. Reduksi asam stearat menghasilkan stearil alkohol. 
Asam palmitat atau asam heksadekanoat adalah asam lemak jenuh yang tersusun dari 16 atom karbon $\left(\mathrm{CH}_{3}\left(\mathrm{CH}_{2}\right)_{14} \mathrm{COOH}\right)$. Pada suhu ruang, asam palmitat berwujud padat berwarna putih. Titik leburnya $63,1^{\circ} \mathrm{C}$. Dari segi gizi, asam palmitat merupakan sumber kalori penting namun memiliki daya antioksidasi yang rendah. Asam linoleat adalah asam lemak omega-6 tak jenuh, diperlukan untuk fungsi otak yang sehat, kulit dan pertumbuhan rambut, kepadatan tulang, produksi energi dan kesehatan reproduksi. Diet yang mengandung 5 sampai 10 persen dari kalori asam omega-6 asam lemak dapat mengurangi risiko penyakit jantung, menurut University of Nebraska-Lincoln Extension. Asam oleat atau asam Z- $\Delta$ 9-oktadekenoat merupakan asam lemak tak jenuh. Asam ini tersusun dari 18 atom $C$ dengan satu ikatan rangkap di antara atom C ke-9 dan ke-10. Asam lemak ini pada suhu ruang berupa cairan kental dengan warna kuning pucat atau kuning kecokelatan. Asam ini memiliki aroma yang khas dan tidak larut dalam air, titik leburnya $15.3^{\circ} \mathrm{C}$ dan titik didihnya $360^{\circ} \mathrm{C}$ (Anonima ${ }^{\mathrm{a}}$ 2018).

\section{Asam Amino}

Asam amino merupakan komponen pembentuk protein. Asam amino berperan penting karena membantu pembentukan protein sebagai bahan dasar pembentuk sel, otot, serta sistem kekebalan tubuh. Asam amino adalah senyawa organik yang memiliki gugus fungsional karboksil $(-\mathrm{COOH})$ dan amina (biasanya $-\mathrm{NH}_{2}$ ). Dalam biokimia seringkali pengertiannya dipersempit: keduanya terikat pada satu atom karbon (C) yang sama (disebut atom C "alfa" atau a). Gugus karboksil memberikan sifat asam dan gugus amina memberikan sifat basa. Dalam bentuk larutan, asam amino bersifat amfoterik: cenderung menjadi asam pada larutan basa dan menjadi basa pada larutan asam (Anonim ${ }^{\mathrm{b}}$, 2018).

Tabel 4.Hasil Analisa Asam Amino Cokelat Putih

\begin{tabular}{|c|c|c|c|c|c|}
\hline Parameter & Unit & A1B1 & A1B2 & A2B1 & A2B2 \\
\hline Aspartat & $\mathrm{ppm}$ & 5433.09 & 6381.89 & 6276.86 & 6814.60 \\
\hline Glutamat & $\mathrm{ppm}$ & 15739.37 & 18145.36 & 23038.53 & 21778.85 \\
\hline Serin & ppm & 4677.92 & 5427.60 & 5476.50 & 6026.70 \\
\hline Glisin & ppm & 2110.90 & 2383.88 & 2205.93 & 2446.60 \\
\hline Histidin & ppm & 1967.87 & 2341.84 & 2472.39 & 2555.21 \\
\hline Arginin & $\mathrm{ppm}$ & 2456.78 & 2819.71 & 2775.57 & 3034.66 \\
\hline Threonin & $\mathrm{ppm}$ & 2976.04 & 3416.65 & 3465.20 & 3693.00 \\
\hline Alanin & ppm & 2766.41 & 3268.87 & 3223.80 & 3530.82 \\
\hline Prolin & ppm & 6741.71 & 7873.01 & 8494.00 & 9101.43 \\
\hline Falin & ppm & 4727.19 & 5439.48 & 5426.20 & 6152.66 \\
\hline Metionin & $\mathrm{ppm}$ & 1876.23 & 2197.23 & 2086.23 & 2396.03 \\
\hline Isouleusin & $\mathrm{ppm}$ & 3691.99 & 4325.86 & 4267.23 & 4786.46 \\
\hline Leusin & $\mathrm{ppm}$ & 6716.81 & 7670.91 & 7669.69 & 8776.09 \\
\hline Phenilalanin & $\mathrm{ppm}$ & 3467.05 & 3990.08 & 4364.05 & 4405.86 \\
\hline $\begin{array}{l}\text { Lisin (Lysine } \\
\mathrm{HCl} \text { ) }\end{array}$ & ppm & 7388.90 & 8500.16 & 8976.45 & 9593.65 \\
\hline
\end{tabular}


Tabel 4 menunjukkan bahwa produk cokelat putih yang dihasilkan mengandung 15 jenis asam amino, tujuh jenis diantaranya adalah termasuk golongan asam amino esensial yaitu treonin, falin, metionin, iso leusin, leusin, phenilalanin dan lisin. Asam amino esensial sendiri merupakan sebuah jenis asam amino yang sangat dibutuhkan oleh tubuh namun tidak dapat diproduksi sendiri oleh tubuh. Hal ini menyebabkan kita memerlukan makanan yang mengandung asam amino esensial untuk memenuhi kebutuhan asam amino esensial di dalam tubuh kita.

Produk cokelat putih yang dideodorisasi (A2B1 dan A2B2) cenderung mengandung asam amino yang lebih tinggi dibanding dengan cokelat putih dari lemak kakao yang tidak dideodorisasi (A1B1 dan A1B2). Hal ini diduga disebabkan pada proses deodorisasi terjadi penghilangan senyawa-senyawa yang menyebabkan bau dan rasa yang tidak diinginkan. Dengan demikian akan terjadi peningkatan konsentrasi senyawa-senyawa lainnya termasuk asam amino. Demikian juga cokelat putih dengan penambahan lemak kakao 30 \% (A1B2 dan A2B2) mengandung asam amino yang cenderung lebih tinggi dibanding cokelat putih dengan penambahan lemak $22 \%$ (A1B1 dan A2B1). Hal ini diduga disebabkan semakin banyak jumlah lemak kakao yang digunakan semakin tinggi pula persentase kadar asam amino cokelat putih yang dihasilkan.

\section{Uji Organoleptik/Citarasa}

Pengujian organoleptik atau citarasa dilakukan dengan 2 metode yaitu uji organoleptik dengan skala hedonik dan uji citarasa dengan panelis terlatih. Pengujian organoleptik penting dilakukan untuk mengetahui tingkat keberterimaan produk yang dihasilkan. Uji organoleptik dilakukan dengan menggunakan metode skala hedonik (hedonic scale) yang meliputi warna, aroma/ bau, tekstur dan rasa oleh 20 panelis. Uji organoleptik cokelat putih ini menggunakan 5 skala hedonik yaitu: sangat suka (5), suka (4), agak suka (3), kurang suka (2) dan tidak suka (1) (Soekarto, 1985). Hasil pengujian organoleptik terhadap cokelat putih yang dihasilkan pada penelitian ini, disajikan pada Tabel 5.

Tabel 5. Hasil Uji organoleptik Cokelat Putih (metode skala hedonik)

\begin{tabular}{ccccc}
\hline \multirow{2}{*}{ Parameter } & \multicolumn{4}{c}{ Skor (Nilai) } \\
\cline { 2 - 5 } & A1B1 & A1B2 & A2B1 & A2B2 \\
\hline Rasa & 3.59 & 3.65 & 3.55 & 3.91 \\
\hline Warna & 3.23 & 2.77 & 4.05 & 3.55 \\
\hline Aroma & 3.00 & 3.23 & 3.27 & 3.77 \\
\hline Tekstur & 3.91 & 3.55 & 3.77 & 3.91 \\
\hline
\end{tabular}

\section{Rasa}

Rasa adalah hal yang terpenting pada sifat organoleptik suatu produk. Salah satu bahan yang mempengaruhi rasa pada produk yaitu gula, Rasa manis adalah sifat rasa yang mempengaruhi cita rasa keseluruhan cokelat (Wahyudi, 2008). Rasa adalah hal yang terpenting pada sifat organoleptik suatu produk. Pada penelitian ini, bahan baku produk cokelat putih memiliki rasa khas yang berbeda. Respon panelis pada produk cokelat putih ini dapat kita lihat pada tabel 5 , dimana skor rata-rata nilai rasa cokelat putih berkisar 3,55 hingga 3,91, yang berarti umumnya panelis memberikan respon suka pada produk cokelat putih yang dihasilkan. Skor nilai rasa yang tertinggi diperoleh dari cokelat putih dengan perlakuan penambahan lemak kakao deodorisasi $30 \%$ (A2B2) dengan skor rata 3,91 yang artinya suka. Tingginya skor nilai rasa pada cokelat putih yang dibuat dari lemak kakao deodorisasi disebabkan lemak kakao yang dideodorisasi mempunyai bau dan rasa yang lebih baik dari pada lemak kakao non deodorisasi. Proses deodorisasi pada pengolahan lemak kakao yang digunakan sebagai bahan baku pembuatan cokelat putih adalah suatu tahap proses pemurnian minyak yang bertujuan untuk menghilangkan bau dan rasa yang tidak enak dalam minyak lemak.

\section{Warna}

Warna yang dihasilkan pada cokelat putih yaitu warna putih cenderung kuning dan mengkilap. Hal ini disebabkan karena warna dasar dari bahan baku yaitu lemak kakao dideodorisasi berwarna kuning 
jernih sedangkan lemak kakao yang tidak dideodorisasi berwarna kuning pudar/pucat. Adapunsusububukyang digunakan berwarna krem atau putih agak kuning. Berdasarkan nilai/skor pada Tabel 5,menunjukkan bahwa skor nilai warna produk cokelat putih berkisar 2,77 hingga 4,05 yang berarti agak suka hingga suka. Cokelat putih yang dibuat dari lemak kakao deodorisasi mendapatkan skor nilai warna yang cenderung lebih tinggi dibandingkan dengan skor nilai warna cokelat putih dari lemak kakao non deodorisasi. Hal ini disebabkan lemak kakao yang mengalami proses deodorisasi menghasilkan warna lemak kakao yang lebih jernih atau cerah sehingga akan mempengaruhi warna cokelat putih yang dihasilkan.

\section{Aroma}

Aroma yang ditimbulkan oleh makanan, banyak menentukan terhadap kelezatan makanan tersebut. Aroma yang ditimbulkan pada umumnya disebabkan oleh perubahan-perubahan kimia dan bentuk persenyawaan dengan bahan lain, misalnya antara asam amino hasil perubahan protein dengan gula-gula reduksi yang membentuk senyawa rasa dan aroma makanan. Dari hasil uji organoleptik aroma cokelat putih, dapat dilihat pada Tabel 5, respon panelis pada aroma yang dihasilkan yaitu pada perlakuan penambahan lemak kakao $22 \%$ non deodorisasi (A1B1) adalah 3,00 yang berarti agak suka. Aroma cokelat putih dari lemak non deodorisasi $30 \%$ (A1B2) adalah 3,23 yang berarti agak suka. Sedangkan aroma cokelat putih pada penambahan lemak kakao deodorisasi $22 \%$ (A2B1) adalah 3,27 yang berarti agak suka dan penambahan lemak kakao deodorisasi 30 $\% \quad$ (A2B2) adalah 3,77 yang artinya suka. Dari hasil uji organoleptik rata-rata panelis memberikan respon cenderung meningkat pada penggunaan/penambahan lemak kakao deodorisasi $30 \%$. Aroma (flavor) merupakan sensasi kompleks yang disusun terutama oleh bau (odor) dan rasa (taste). Selain disusun oleh kedua faktor tersebut, aroma juga dipengaruhi oleh kepekaan indra perasa dan respon suhu. Menurut Reineccius (2006), mayoritas penelitian tentang aroma yang dilakukan sejak dahulu merupakan penelitian tentang unsur volatil pada makanan dan pencita rasa.

Pada kakao, terdapat beberapa golongan senyawa yang penting dalam pembentukan aroma. Menurut Maarse (1991), beberapa senyawa yang berperan dalam pembentukan aroma kakao antara lain senyawa-senyawa hidrokarbon, alkohol, aldehida, keton, asam karboksilat, ester, furan, fenoldan eter, furan, pirol (pyrroles), oxazoles,thiazoles, piridin (pyridine) dan quinolines, pirazin, amina, komponenkomponen bersenyawa nitrogen serta komponen bersenyawa belerang.

\section{Tekstur}

Tekstur adalah bagian dari sifat organoleptik pada produk. Faktor yang dapat mempengaruhi baik tidaknya produk cokelat yaitu pada penghalusan dan pencampuran bahan yang digunakan serta ada tidaknya pengemulsi (Minifie, 1999). Bahan yang tidak halus dan tidak tercampur rata, akan menyebabkan tekstur yang kasar. Dari hasil uji organoleptik tekstur cokelat putih (Tabel 5) menunjukkan bahwa nilai rata-rata terhadap tekstur cokelat putih yang dihasilkan yaitu berkisar dari 3,55 hingga 3,91 yang berarti umumnya panelis memberikan tanggapan suka terhadap semua produk cokelat putih yang dihasilkan. Hal ini disebabkan pada proses pengolahan pembuatan cokelat putih digunakan proses conching yang sama dengan suhu dan waktu yang sama pula untuk semua perlakuan yang digunakan, sehingga dihasilkan tekstur yang cenderung sama pula. Selain dilakukan pengujian organoleptik (skala hedonik) juga dilakukan pengujian citarasa dengan menggunakan panelis terlatih pada laboratorium Puslitkoka Jember. Pengujian cita rasa dilakukan terhadap beberapa karakteristik yang berhubungan dengan produk cokelat. Adapun hasil pengujian cita rasa produk cokelat putih dapat dilihat pada Tabel 6. Dari Tabel 6, terlihat bahwa nilai preference produk cokelat putih berkisar antara 7,17 - 7,50. Nilai ini menunjukkan bahwa tingkat keberterimaan untuk semua produk cokelat putih yang dihasilkan dari penelitian ini adalah good. 
Tabel 6. Hasil Uji Cita Rasa Cokelat Putih

\begin{tabular}{lcccc}
\hline \multicolumn{1}{c}{ Karakteristik } & A1B1 & A1B2 & A2B1 & A2B2 \\
\hline Chocolate aroma & 6.83 & 7.17 & 7.00 & 7.33 \\
\hline Intensity of aroma & 5.50 & 5.17 & 5.33 & 5.00 \\
\hline Chocolate Flavour & 7.00 & 7.17 & 7.17 & 7.33 \\
\hline Intensity of flavour & 5.67 & 5.50 & 5.33 & 5.00 \\
\hline Acidity & 7.50 & 7.50 & 7.33 & 7.50 \\
\hline Intensity of acidity & 3.16 & 3.33 & 3.50 & 3.33 \\
\hline Bitterness & 7.50 & 7.50 & 7.33 & 7.58 \\
\hline Intensitas of bitterness & 3.17 & 3.00 & 3.50 & 3.00 \\
\hline Astringent & 7.50 & 7.50 & 7.33 & 7.58 \\
\hline Intensity of astringent & 3.33 & 3.00 & 3.67 & 3.00 \\
\hline Caramelly & 7.17 & 7.00 & 7.50 & 7.33 \\
\hline Intensitas of caramelly & 5.50 & 5.00 & 5.70 & 5.00 \\
\hline Creamy & 7.33 & 7.67 & 7.33 & 7.83 \\
\hline Intensity of creamy & 0.00 & 0.00 & 0.00 & 0.00 \\
\hline Sweetness & 7.33 & 7.50 & 7.33 & 7.50 \\
\hline Intensity of sweetness & 6.17 & 6.33 & 5.67 & 4.33 \\
\hline Texture/Colour: & 7.33 & 7.67 & 7.50 & 7.83 \\
\hline Intensity of texture/colour & 0.00 & 0.00 & 0.00 & 0.00 \\
\hline Taints/Off-flavours & $\mathrm{Nil}$ & $\mathrm{Nil}$ & $\mathrm{Nil}$ & $\mathrm{Nil}$ \\
\hline Preference & 7.17 & 7.50 & 7.42 & 7.50 \\
\hline
\end{tabular}

\section{SIMPULAN DAN SARAN}

\section{Simpulan}

Cokelat putih yang diolah dari lemak kakao non deodorisasi mempunyai kadar air $1,46-1,52 \%$, kadar gula 48,25 - 55,76 \%, kadar lemak 31,99 - 37,79 \%, FFA 1,53 - 1,58 $\%$, titik leleh $42-51^{\circ} \mathrm{C}$, sedangkan cokelat putih yang diolah dari lemak kakao deodorisasi mempunyai kadar air 1,55 - 1,62\%, kadar gula 48,84 - 54,85 \%, kadar lemak 32,61 - 36,14 $\%$, FFA $1,11-1,15 \%$, titik leleh $40-49{ }^{\circ} \mathrm{C}$. Kandungan asam lemak pada cokelat putih dari lemak kakao deodorisasi cenderung lebih rendah dari cokelat putih dari lemak kakao non deodorisasi. Sebaliknya kandungan asam amino pada cokelat putih dari lemak kakao deodorisasi lebih tinggi dibanding cokelat putih yang diolah dari lemak kakao non deodorisasi. Cokelat putih dari lemak kakao non deodorisasi dan deodorisasi mempunyai tingkat keberterimaan citarasa kategori "good".
Saran

Perlu dilakukan penelitian selanjutnya untuk mengetahui daya tahan cokelat putih.

\section{DAFTAR PUSTAKA}

Anonima, 2018. Jenis-jenis Asam Lemak (https://www.scribd.com/ doc/249917071/Pengertian-AsamLemak, diakses 28-3-2018)

Anonimb $^{b}$ 2018. Asam Amino. (https:// id.wikipedia.org/wiki/Asam_amino, diakses tgl 28-3-2018).

Anonim, 2014. Titik Lebur. https:// www. slideshare.net/eggaodontiatres/titiklebur.Diakses tanggal 27-11-2018.

Atkinson, Catherine, Mary B., Christine F., McFadden C., (2010). The Chocolate and Coffee Bible.Hermes House.ISBN 978-1-84477-385-5.

Brown, A.C. 2010. Understanding Food: Principles and Preparation. Yorkshire: Wadsworth Publishing. 
Becket, S.T., (2009). Industrial Chocolate Manufacture and Use $4^{\text {th }}$ Edition, WileyBlackwell Ltd.

BSN, 1992. SNI Cara UjiGula (SNI 01-28921992). BadanStandarisasiNasional, Jakarta.

BSN, 2009. SNI LemakKakao (SNI 37482009). BadanStandartisasiNasional, Jakarta.

BSN, 1992. SNI Cara UjiMakanandanMinuman(SNI01-28911992). BadanStandarisasiNasional, Jakarta.

BSN, 2014. . SNI Cokelat Dan ProdukProduk Cokelat.SNI 7934-2014. BadanStandartisasiNasional, Jakarta.

FrancisF.J.1999. Wiley Encyclopedia of Food Science and Technology.JohnWiley and Sons.

Gibon, V., Wim D. Greyt, and M. Kellens. (2007). Palm Oil Refining. European

Journal of Lipid Science and Technology Vol 109: 315-335.

Guehi, S.T., et al., 2008. Impact on cocoa processing technologies in free fattyacids formation in stored raw cocoa beans. AfricanJ.of Agric.Res. Vol.3(3).pp.174-179.

Ketaren, S. 2008. Pengantar Teknologi Minyak Dan Lemak Pangan. Cetakan Pertama.Universitas Indonesia Press. Jakarta.

Khomsan. A. 2003. Pangan dan Gizi untuk Kesehatan. Jakarta: PT. Rajagrafindo

Maarse, 1991. Volatile Compounds in Foods and Beverages. Marcel Dekker inc. New York-Basel-Hongkong.

Minifie, 1999. Minifie, B.W. 1999. Chocolate, Cocoa, and Confectionery: Science and Technology 3rdEdition. Van Nostrand Reinhold. New York.
Mulato, S., Widyatomo, S., Misnawi, Suharjono, E., 2010. Pengolahan Produk Primer dan Sekunder. Puslitkoka, Jember.

Pangerang, F., (2012),Pengaruh Penambahan Susu Kedelai dan Gula Berkalori Rendah Untuk Produk Coklat Truffle Sebagai Pangan Fungsional, Thesis: Fakultas IImu dan Teknologi Pangan, Universitas Hasanudin,Makasar

Reineccius, G. (2006). Flavor Chemistry and Technology. Taylor \& Francis. USA.

Ramlah,S. dan Yumas,M. 2017. Pengaruh Formulasi Dan Asal Biji Kakao Fermentasi Terhadap Mutu Dan Citarasa Dark Chocolate.Jurnal Industri Hasil Perkebunan .Balai Besar Industri Hasil Perkebunan Makassar.

Soekarto,S.T. 1985. Penilaian Organoleptik untuk Industri Pangan dan Hasil Pertanian.Bhratara karya Aksara. Jakarta.

Star, Michael and Other, E \& OE. 2006. Healthy Chocolate? Cocoa is TheBest Antioxidant Food. http://www. astrologyzine.com/healthy-chocolates. Diakses 11 april 2006.

Timms, R.E., 2003. Confectionery fats handbook: properties, production and application, The oily press.

Wahyudi, 2008.Wahyudi, T., T.R. Panggabean, and Pujiyanto. 2008. Panduan Kakao Lengkap, Manajemen Agribisnis dari Hulu hingga Hilir. Penebar Swadaya, Jakarta.

Wahyudi,T., Pujiyanto, dan Misnawi.2015. Kakao : Sejarah, Botani, Proses Produksi, Pengolahan, dan Perdagangan. Gadjah Mada University Press.ISBN 978-979-420-966-0. 